\title{
MIGRATION POLICY AS A FACTOR OF NATIONAL ECONOMIC SECURITY
}

\author{
Tatiana Podolskaya \\ Ekaterina Mediakova
}

Nina Kolesnikova

Russian Presidential Academy of Economy and Public Administration (RANEPA)

Rostov-on-Don, Russia

Authors consider the impact of migration processes on the state of country's security. The other actual direction of this research is to identify the dependence of country's economic security on the intensity of migration regulation. The complexity of assessing global trends in migration policy leads to the need for a comparative analysis of the conditions for their implementation in the context of world labor migration centers. The paper analyzes the main tools of migration policy, the study of which made it possible to summarize and identify measurable indicators of the impact of migration processes on the state of economic security.

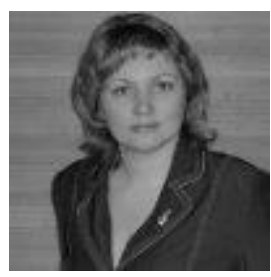

Tatiana Podolskaya

is a candidate of economical sciences (since 2003); $\mathrm{PhD}$ - candidate in Russia Presidential Academy of National Economy and Public Administration, Rostov-on-Don, Russia (since 2008) and associate professor of department of international economy.

Her scientific interests are concentrated around international financial system, government and international regulation of global finance market.

Since 2005 she published more than 20 articles in Russian federal and international journals; participated more than 30 International scientific - practical conferences.

E-mail: tv.kuraeva@mail.ru

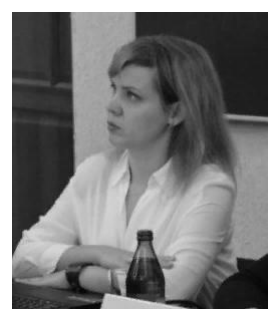

Ekaterina Medyakova

is a Candidate of Economic Sciences, Associate Professor, Director of the Center for Advanced Studies of the Faculty of Further Professional Education at South Russian Institute of management of Russian Presidential Academy of Economy and Public Administration (RANEPA). The area of scientific interests includes issues of trends of modern world economy, features of public procurement, greening the economy. Ekaterina Medyakova is the author of more than 80 scientific papers, 5 textbooks, 2 monographs.

E-mail: meo@uriu.ranepa.ru

Nina Kolesnikova

is a Candidate of Philological Sciences, Associate Professor of Department of Foreign Languages. the areas of scientific interest include language theory (lexicology, semasiology), teaching English for professional purposes, economic security, international business and business communication. She has over 45 years of teaching experience at Rostov-on-Don Teachers Training Institute, Russian Customs Academy and Russian Presidential Academy of National Economy and Public Administration. She has written various language programs and resource books for pre-work students of Foreign Languages Department, Customs Administration Department and Economy Department. She has been teaching General English, Business English, English for Professional Purposes and delivering elective courses in Intercultural Management and Organizational Management.

E-mail: meo@uriu.ranepa.ru 


\section{MIGRATION POLICY AS A FACTOR OF}

The complex of designated challenges and threats to the economic security of the state will allow to form an overall picture of the current state of the object and a qualitative mediumterm forecast.

Keywords: migration; economic security; migration policy; the OECD; the Universal Declaration of Human Rights; labor export; the Corruption Perception Index; migration turnover rate

\section{Instruments of Migration Policy: Current state of development}

One of the instruments of migration policy is represented by the intergovernmental agreements on foreign labor employment, which include the conditions of migrants' stay in a host country, the observance of which is intended to protect migrant workers' interests. Intergovernmental agreements on foreign labor hiring, concluded between the Federal Republic of Germany and the sending countries, stipulate that employers hire and pay foreign workers on the basis of the same provisions of tariff agreements applicable to German workers. Immigration control services monitor the entry of immigrants into the country. In accordance with the entrepreneurs' statements about their need for specific categories workers, they are issuing entry permits for a specific period of time.

International migration agreements can be subdivided into two groups: bilateral and multilateral. Such agreements set quotas and limits to migrants' entry into the territory of one or another party. Multilateral agreements are concluded between the EU countries, for example. Their key objective is regulating the immigration from the non-EU countries. Such agreements are usually implemented through national labor departments.

The Federal Office of Industry, Crafts and Labor in Switzerland, the Ministry of Labor in Finland, the State Administration for Foreign Affairs in China are the examples of such official bodies.

The procedure for concluding immigration agreements includes a precise sequence of actions. The sending party carries out a preliminary selection of candidates in accordance with the criteria agreed upon with a host party. The sending party's authorized body checks the compliance of the proposed migrant candidates with the conditions of the international agreement, and then it sends the received information to the receiving party's authorized body.

Certain restrictions may be applied by the receiving party. Some categories of workers are excluded from these restrictions, for example:

1. Low-qualified personnel working in difficult and hazardous working conditions, applying for low-paid jobs;

2. Specialists of rare professions, such as restorers of paintings and ancient manuscripts, archaeologists, doctors, practicing non-traditional methods of treatment;

3. Experts in top priority areas of economy;

4. Senior managers of enterprises, organizations or their branches, businessmen who have granted the right to do business in a host country;

5. Highly qualified specialists and creative professionals (artists, composers, musicians etc.).

There is very little reliable information about the scale of illegal immigration, but each state is aware of this phenomenon and takes it into account when forming its own migration 
policy. By some estimates, illegal immigration has increased tenfold in the recent decade only. One of the reasons for such rapid growth is availability of cheap labor in many developing countries worldwide which tempts employers to hire illegal immigrants and thus get easily managed staff for much lower cost (Revision of World Urbanization Prospects, 2018).

Another serious problem is repatriation, that is, the return of foreign workers to the country that is legally their own after their contract expires. Immigrants will inevitably face the economic, social and psychological problems at home countries so they tend to resist getting back there. Therefore, some Western European countries have developed programs to encourage the repatriation of migrants.

Parallel efforts are made to govern immigration processes and develop government programs to regulate emigration. These programs are essential for the countries actively exporting labor resources. They ensure that the emigrant workers' rights and interests are protected, and discriminatory actions against them are properly addressed; and nation's losses due to movement of labor resources outside the country are compensated.

The emigration policy is usually based on the principles stated below:

1. Providing the possibility of migrants' return to their own country in the future;

2. Ensuring entry into the territory of the country and further effective distribution of workers;

3. Reducing domestic unemployment through elimination of unclaimed labor;

4. Improving the quality of the domestic labor market through hiring the repatriates who have improved qualifications.

Labor emigration processes are regulated by legal and regulatory documentation, based on the country's constitution, national emigration legislation, and international migration agreements.

In case of migration laws' violation, both the emigrant and the facilitators contributing to it are held responsible. Upon returning to their own country, individuals who emigrated illegally or those who broke the contract terms are subject to certain sanctions, including fines or imprisonment (Turkey is notoriously famous for such measures, for example). The intermediary provider may also be subject to penal measures and may be deprived of a license, and also financial sanctions may be applied if they fail to fulfill their duties in a proper way (Př́ivara, 2017).

Labor export especially that of low-skilled labor has a number of positive implications for donor countries. When the unemployed leave, the unemployment rate in the country decreases, this consequently eases social tensions and reduces the state's financial obligations to pay unemployment benefits.

Labor export brings foreign currency to the donor country from direct sources:

1. Tax payments from the profits of intermediary firms;

2. Emigrants' direct remittances to their country, to support families and relatives;

3. Migrants' investments in their country's economy (through establishment of industrial enterprises, acquisition of movable and immovable property etc.);

4. Income from the countries importing labor which stimulates economic growth.

Importantly, labor export brings income quite comparable in volume with the profit from the trade in consumer goods. According to the experts of the World Economic Forum, in 2017 labor migrants transferred back to their families in developing countries around \$466 bln, which greatly exceeds the investments into these countries and the economic assistance 


\section{MIGRATION POLICY AS A FACTOR OF}

from the international community. About $800 \mathrm{mln}$ people worldwide received direct financial support from their relatives working abroad. In 2017, the countries whose migrants sent home the most were: China (62.7 bln USD), India (61 bln USD), the Philippines (29.9 bln USD), and Mexico ( 28.5 bln USD). In some countries, the share of remittances from labor migrants makes up a significant share of GDP. According to this indicator, the leaders are Kyrgyzstan (34.5\% of GDP), Nepal (29.7\%), Liberia (29.6\%), Tajikistan (26.9\%) and Moldova (21.7\%) (World Economic Outlook, 2018)

Calculations make it possible to estimate that the efficiency of monetary exports from labor migrants is at least 5 times higher than the monetary efficiency of food exports. In recent years, re-immigrants have imported a sufficiently large number of industrial goods intended for setting up small production enterprises in their home countries. In most cases, the governments of these countries are committed to maximizing such imports by reemigrants. With this purpose in mind, they reduce or completely remove customs duties, thereby contributing to the development of local small businesses, as well as to increased employment and job creation in the country. They also encourage imports of consumer goods, which undoubtedly allow saturating the domestic market with scarce exports.

Labor migrants increase Germany's GDP growth by $0.2 \%$ per year on average. The most beneficial effect from the migrants' inflow over the last five years was in 2015, an additional increase was $0.3 \%$, which in general resulted in a $1.5 \%$ increase in GDP (IOM GMDAC, 2019).

The German Institute for Economic Research (DIW) also concluded that since 2011, the inflow of fairly highly skilled labor from abroad has provided German economy with substantial benefits, as reflected in GDP growth and many other vital indicators. It is noteworthy that the greater proportion of those who have immigrated to Germany since 2011 (more than $9 \mathrm{mln}$ people) are residents of other EU countries (mainly Bulgaria, Romania, Greece, Italy and Spain). This flow of emigrants was caused by the removal of restrictions on employment within the European Union.

The DIW experts note the crucial significance of this policy for Germany's economy. The country has seen a massive reduction in the number of skilled workers due to the general aging of population and other demographic challenges. Moreover, to cope with the problem of a significant reduction in the volumes of the country' economically active population (projection - from a decrease of $16 \mathrm{mln}$ people to a decrease of one third of the total number in case of the most negative scenario), Germany should be receiving annually 260,000 labor migrants until 2060.

The DIW experts believe that 114,000 labor migrants will arrive in Germany from other EU countries, but demographic factors and the convergence of the economies in the EU countries will reduce Germany's attractiveness for foreign workers from Europe. The remaining 146,000 migrants per year will have to arrive into the country from outside the EU. According to official data, only 38,000 foreign workers arrived in Germany in 2017 (German Institute for Economic Research, 2019).

To achieve such a significant increase, the state should radically reconsider its migration policy. In general, overcoming demographic challenges seems to rely on creating favorable environment for combining family and work responsibilities, investing heavily (at least sufficiently) in employment programs, advanced training and mobility of the young working-age population, determining the optimal size of migration of highly qualified specialists. It is common knowledge that labor market mobility and flexibility are not only a 
means of dealing with the global economic crisis, but also an effective instrument for economic revival in the period of crisis overcoming.

\section{Formation of the Strategy of Economic Security Taking into Account Migration Processes}

Ensuring economic security is one of the basic functions of the state, the understanding of which came only in the twentieth century. The definition itself was coined back in 1934 by F. Roosevelt, who used the phrase "national economic security" in the speech about the Great Depression. In the post-war period already, in 1947, the US administration adopted the law "On National Security" and introduced the National Security Council under the US President, thus fixing the need for security in the economy at the legislative level.

In Russia, legislative consolidation of this concept is reflected in the Decree of the President of the Russian Federation as of May 13, 2017 No. 208 "On the Strategy of the Economic Security of the Russian Federation for the Period up to 2030", where "economic security" refers to the state of protection of the national economy from external and internal threats, which ensures economic sovereignty of the country, the unity of its economic space, conditions for the implementation of the strategic national priorities of the Russian Federation.

At the same time, the available research studies do not provide a unified understanding of this definition; experts tend to base it on the approach "from the opposite": the absence of internal threats to integrity, the absence of destructive external influence and so on. However, they agree that economic security is a balanced state of the country's economy that does not depend on time periods. The authors view national economic security as a set of interrelated components, generating a synergy effect of sustainable economy: uninterrupted production supplies, the volume and capacity of fixed assets, research and technological innovation development; sales opportunities at the markets, both domestic and international, labor force development (Arkhipov, 2017).

Stability of the economy, in turn, implies strength and reliability of its components, vertical, horizontal and other links within the system, its resilience to external stresses. Thus, economic security strategy provides such a state of sustainable development in the country's economy, when its vulnerability to any external stress is minimal. The other key factors of national economic security are the scale and the contents of changes in the country's economy.

Measurability of economic security, risks and threats in quantitative values is indisputable, but it is not possible to suggest a reference model, based on a set of criteria. The reason is primarily that the indicators and set threshold values directly depend on the basic indicators of a country's economic development. Furthermore, causal linkages, relationships and interactions between the indicators could justify the application of various sets of indicators (on equal footing). National economic security strategy gives priority to development of a state regulation system and selection of its own set of the most acceptable indicators. Before considering the impact of migration on this area, it is necessary to state that country's economic security strategy is based on threats and challenges. The threat to economic security is a set of conditions and factors that create a direct or indirect possibility to damage national interests of a state in the economic sphere. Challenges to national economic security include a complex of factors that can, under certain conditions, lead to the 


\section{MIGRATION POLICY AS A FACTOR OF}

emergence of a threat to economic security. It is noteworthy, that in Russia, threats and challenges, among other things, include increased international competition for highly qualified specialists, as well as lack of internal domestic labor resources (Samarina et al., 2018).

The authors believe that in examining the impact of migration on national economic security, one should take into account the ongoing shift to digital economy worldwide. In the context of this paper, digital economy refers to the whole range of economic relations based on digital computer technology and new conditions of informatization, data generating, processing, storage and transmission. Thus, it is necessary to make a distinction between assessing the impact migration has on digital economy and that on traditional materialized economy. Digital economy is essentially designed to erase boundaries between various parties, thus reducing the need for relocation due to economic reasons.

The rapidly growing number of users of various electronic systems, electronic media, digital workflow, digitalization of some actions and operations of economic agents, and in general - the shift to digital economy, education and public services should be acknowledged as another generally recognized feature of today's developed society.

The task of transition to the digital format is declared as the key trend in the world development, its impact is intensifying in the long term as more and more participants become involved. In the digital era, qualitative upgrading of relations has great potential for economic growth and implementing innovation-oriented course in business and industry development. New areas of digital economy and their applications are the subject of discussions on the global scale. The concept of Industry 4.0 which declaratively defines the stages of the Fourth Industrial Revolution got its name in 2011 and was initially defined as a means of making industrial sector more competitive through enhanced integration of "cyberphysical systems," or CPS, into production (manufacturing).

However, by 2018, with the increasing global interaction of various processes a far broader understanding emerged. The new business linkage and interaction between real, materialized economy and the digital one will result in a fundamental change in migration flows' formation and directions and, accordingly, in migration policy. These days there is a growing demand for qualified workers of a certain type, those with "digital" competences. The state of labor resources themselves and most important, the need for workers of particular professions and jobs and responsibilities they can take, will also undergo considerable changes. The projection period of business operations' digitalization is likely to see diminished activity of some parts of migration flows: under favourable domestic conditions for economic agents' operations in the digital environment, there is no need (for them) to move to other territories. Undoubtedly, the other reasons for migration - political, social, man-made ones - will still remain the drivers for migration flows.

The projected transition to the digital format implies that even big global businesses will be transformed into the so-called digital platforms, with merging of production, services, social and telecommunications network. For example, the financial holding of BlackRock (assets under management as of the beginning of 2017 exceeding 4.89 bln USD) already operates its own trading platform which reduced, by several times, the company's costs for material and technical maintenance (Special Eurobarometer, 2019). For such companies a special strategy for managing human resources is also being developed. The strategy aims to reduce the number of low-skilled workers and replace them with automated programs as well as to attract highly qualified personnel with digital competencies. As noted above, the 
demand for the latter significantly exceeds the supply, whereas the former lose their jobs. Without competent management, large-scale information flows that globalization brought about with digital communication resources, can pose a significant threat to the economy of any country.

Thus, a high risk of security threats prompted a nearly universal ban on the use of cryptocurrencies worldwide, because cryptocurrencies, due to their specific nature, could provide a conditional anonymity, and thus, may lead to a variety of unlawful actions. So the downside to digitalization is that it can be used as an effective tool for money laundering, corruption and financing illegal activities, including terrorism. That is, the focus of a real threat to economic security is shifting towards digital environment, with some states not having worked out a national concept to combat this threat.

In a material economy, migration flows remain to be a significant factor, both directly and indirectly affecting the basic indicators of countries' economic security. Directly through decrease in labor supply at the market of the country with surplus labor force and an increase in the supply in the country that lacks labor resources. Migrants' remittances can be an example of an indirect impact in this regard.

As the international labor market is being established, economic and technological sectors are integrated, with the more complex area of social and labor relations becoming global and getting involved in the integration process. Worldwide, nations base their social policies on social experiences and local traditions. The points of contact are joint multinational enterprises and corporations set up all around the world. Contacting also occurs within some TNCs, thus crossing labor and capital boundaries. In many cases, this process results in the challenge of integrating not only different economic and technological structures, but social ones as well. This overlap should obviously take the following directions (Strack et al., 2018):

- working conditions, methods of hiring and firing staff;

- remuneration of workers, including additional payments system;

- the number of working leaves allowed;

- the number of working hours per week/month;

- the system of extra benefits, including material ones, recreation opportunities etc.

Harmonizing various social practices in many other areas (labor union activities, conflict resolution etc.) could be a challenge too.

Today there are five major international regional labor markets: West European, Middle Eastern, Asian, Latin American, and African. The international labor market is being formed in two ways:

1) through migration (physical movement of capital and labor);

2) by gradual merging of national labor markets (the establishment of a "common labor market") when legislative, national-ethnic, cultural and other barriers being overcome.

In some cases, a combination of capital and labor can occur even without their physical movement, when telecommunication systems are involved. Thus, the typology of labor resources migratory movement can be represented as follows:

- by duration period: regular (assuming a return), irregular (permanent);

- by residence and restrictions on employment: based on contracts and deals;

- by the legal status of migrants: legal and illegal (undocumented and documented migrant workers);

- by various professional qualification levels. 


\section{MIGRATION POLICY AS A FACTOR OF}

Regular-type migration can be classified into the free-movement migration, permanent relocation (settlement) and authorized residence permit. Each classification subgroup remains a factor affecting economic security of the state.

Research on potential international migration reveals that it is represented by active young professionals, disadvantaged in the social and employment aspects.

However, within 5-10 years, the earnings in the former group increase significantly, which is largely due to "natural selection process" among foreign-born workers: the group is made up of the most capable and motivated people. This is primarily due to significant changes in the requirements (recently imposed) on the know-how and expertise of many technical workers in line with rapid developments in microelectronics and the IT sector in general. These days, shortfalls in the workforce with required qualifications are made up by hiring professionals from other countries on temporary contracts, increasing the territorial mobility of skilled labor, diversifying terms of employment and organizing work for these categories of workers.

\section{Conclusions: \\ Generalized Indicator of the Correlation between Migration Processes and Economic Security Indicators}

The authors attempted to create a generalized indicator of the correlation between the migration processes and the economic security indicators. The current situation in the world economy makes it possible to classify labor migration, regulated in varying degrees, into three types of flows.

The labor migration of the first type: from less economically developed countries to more developed ones (from developing economies to developed countries; from former socialist countries to developed countries). As a working hypothesis for selecting indicators of the impact of this type of migration on economic security of a country, the following was adopted: the size of the migration turnover rate proportionally reduces the indicators of country's economic security.

The migration turnover rate is measured as the minimum of gross immigration and gross emigration over the period as a percentage of population in the area. The study analyzed and ranked 30 representative countries according to the accepted classification - 10 developed countries, 10 developing countries, 10 countries with economies in transition.

According to the statistics available in the aggregated access, the number of immigrants and emigrants was estimated with respect to the average annual population, from 2016 to 2018.

Data analysis of the given factors dynamics in comparison with the growth/decline in GDP, foreign direct investment flows and The Corruption Perceptions Index can suggest the following conclusions. In developed countries, GDP has the strongest correlation with the changes in the migration turnover rate.

The Corruption Perceptions Index changed slightly and the foreign direct investment flow was much less affected by the coefficient under consideration. In the countries with transitional economies, the GDP level and The Corruption Perception Index had equal volatility and a pronounced link with the migration turnover rate, whereas the dynamics of investment changed at a much lower rate. 
In developing countries, the migration turnover rate was directly linked to the GDP and the volume of investment flows, The Corruption Perception Index was not affected.

Labor migration of the second type: between the countries of the same level of development (for example, between fully developed economies or between countries at the roughly the same development stage). As a working hypothesis, it was found that both intensity and efficiency of migration affects economic security only indirectly, through transformation of the qualitative characteristics of the labor force. The correlation between intensity of the migration turnover rate and migration effectiveness rate in relation to the unemployment rate at the domestic market was estimated. The sample presented above allowed us examine the impact of this type of labor migration on the economic security criterion. The calculations carried out on the three groups of countries did not reveal any permanent pronounced correlation. The dynamics of changes in the combination of these indicators for all types of countries was observed, but no proportionality was revealed. The result shows the need for research over a longer period, subject to the countries carefully keeping track of these criteria; as well as the influence of a large number of additional factors not taken into account in this analysis.

Current economic and political world events have left a significant imprint on the international migration processes. Considering the need to transform the instruments of migration policy in the future, it is worth noting that the economy of the future implies secure, non-discriminatory and transparent management of all existing resources, including labor. Digitalization and other trends considered in this paper set the task of transforming the migration policy, pose new challenges to economic security and require a new approach to labor force training.

The described effects of the migration processes on national economic security, as well as the latter's dependence on migration regulation, suggest that it is necessary to create a model of indicators that would allow for periodic monitoring of its impact and assessment of its consequences. This model should be compiled, firstly, from a series of generally accepted coefficients to assess the impact of migration on the selected indicators of economic security. This proposal is based on the thesis of minimizing the cost of conducting statistical studies and generating databases over time.

Secondly, the specifics of a country could be determined by an additional level of indicators characterizing the reference state of economic security in a country. The selected indicators should also take into account the threshold values of security threats in conjunction with migration processes. It can be assumed that inclusion of migration as an aspect of the reference state of national economic security might be conductive for choosing the most effective instruments of migration policy.

\section{References:}

Arkhipov, A. \& Kozlova, E. (2017). Migration dynamics in Russia economy development: factors, patterns, concepts of administration. The EUrASEANs: journal on global socioeconomic dynamics, 1(2)

Immigration from other EU countries has increased Germany's economic growth since 2011. (2018).

German Institute for Economic Research. Retrieved on 28.02.2019 from: https://www.diw.de/de/diw_01.c.605566.de/themen_nachrichten/zuwanderung_aus_anderen_e u_laendern_hat_deutschland_seit_2011_zusaetzliches_wirtschaftswachstum_beschert.html\%20 


\section{MIGRATION POLICY AS A FACTOR OF}

IOM GMDAC

(2019).

Retrieved

on

28.02.2019

from https://migrationdataportal.org/themes/migration-policies-and-governance .

Privara, A. (2017). Female labor force participation in the EU countries. The EUrASEANs: journal on global socioeconomic dynamics, 5(6).

Revision of World Urbanization Prospects (2018). United Nations.

Samarina, V., Skufina, T. \& Samarin, A. (2018). Migration and socioeconomic effectiveness of Russia's northern regions. The EUrASEANs: journal on global socioeconomic dynamics, 5 (12).

Special Eurobarometer (2019). Wave EB75.4 - TNS opinion \& social. Retrieved on 28.02.2019 from: http://ec.europa.eu/commfrontoffice/publicopinion/archives/ebs/ebs_370_en.pdf.

Strack, R., Booker, M., Kovács-Ondrejkovic, O., Antebi, P. \& Weltch, D. (2018). Decoding global talent 2018. Boston Consulting Group. Retrieved on 28.02.2019 from https://www.bcg.com/publications/2018/decoding-global-talent.aspx .

Trends in international migrant stock (2017). Retrieved on 28.02.2019 from http://www.un.org/en/development/desa/population/migration/data/estimates2/estimates17.asp.

World Economic Outlook (2018). October 2018: Challenges to Steady Growth Retrieved 28 February 2019 from: https://www.imf.org/en/publications/weo.

World Economic Outlook (2019). Growth Slowdown, Precarious Recovery. Retrieved on 24.04.2019 from: https://www.imf.org/en/publications/weo.

World Economic Outlook Update (2019). A Weakening Global Expansion. Retrieved 24.04.2019 from: https://www.imf.org/en/publications/weo.

Paper submitted

Paper accepted for publishing

Paper published online
16 July 2019

18 October 2019

30 November 2019 